Research Paper

\title{
Polyomaviruses detectable in head and neck carcinomas
}

\author{
Leonard Poluschkin ${ }^{1}$, Jaana Rautava ${ }^{1,2}$, Aaro Turunen ${ }^{1}$, Yilin Wang ${ }^{3}$ Klaus \\ Hedman $^{3}$, Kari Syrjänen ${ }^{4}$, Reidar Grenman ${ }^{5}$ and Stina Syrjänen ${ }^{1,2}$ \\ ${ }^{1}$ Department of Oral Pathology and Oral Radiology, Institute of Dentistry, Faculty of Medicine, University of Turku, 20520 \\ Turku, Finland \\ ${ }^{2}$ Department of Pathology, Turku University Hospital, 20521 Turku, Finland \\ ${ }^{3}$ Department of Virology, University of Helsinki, and Helsinki University Hospital, 00290 Helsinki, Finland \\ ${ }^{4}$ Department of Clinical Research, Biohit Oyj, 00880 Helsinki, Finland \\ ${ }^{5}$ Department of Otorhinolaryngology - Head and Neck Surgery, University of Turku and Turku University Hospital, 20520 \\ Turku, Finland \\ Correspondence to: Stina Syrjänen, email: stina.syrjanen@utu.fi
}

Keywords: polyomaviruses; SV40; JCV; BKV; head and neck cancer

Received: July 02, $2017 \quad$ Accepted: March 22, $2018 \quad$ Published: April 27, 2018

Copyright: Poluschkin et al. This is an open-access article distributed under the terms of the Creative Commons Attribution License 3.0 (CC BY 3.0), which permits unrestricted use, distribution, and reproduction in any medium, provided the original author and source are credited.

\section{ABSTRACT}

Polyomaviruses (PyV) independent or jointly with human papillomavirus (HPV), might have a role in head and neck carcinomas (HNSCC). We analyzed the prevalence and viral DNA loads of SV40, JCV and BKV with quantitative PCR (qPCR) and all 13 HPyVs with a novel Multiplex method in 82 HNSCC samples with known HPV status and disease-specific survival (DSS) and 24 HNSCC cell lines.

JCV was the most prevalent PyV present in $37 \%$ of HNSCC and the most prevalent sites were lip ( $80 \%)$, larynx $(67 \%)$ and oral cavity $(59 \%)$. JCV viral load was highest

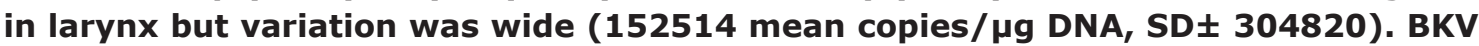
was found only in one oral carcinoma with low viral load. SV40 was detected in $60 \%$

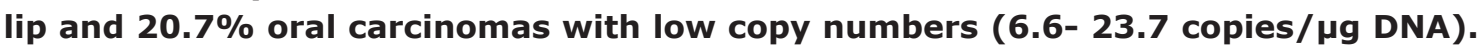
Altogether, $86 \%$ of JCV-positive samples were co-infected with HPV $(p=0.001)$, with no impact on DSS. Agreement between qPCR and Multiplex methods was substantial (Cohen's kappa $=0.659$ ). Multiplex method detected additional HPyV in five samples. JCV was found in 9/24 HNSCC cell lines, all deriving from oral cavity. Our data provide evidence that JCV might have a role in HNSCC as independent virus or co-factor of HPV.

\section{INTRODUCTION}

Head and neck cancers (HNSCCs) comprise a heterogeneous group of tumors including cancers of the lip, oral cavity, nasal cavity, paranasal sinuses, nasopharynx, oropharynx, hypopharynx, larynx and salivary glands. Nearly $90 \%$ of these malignancies are squamous cell carcinomas (SCC). HNSCCs represent a major global cancer burden, with over 686.000 annual new cases. The age-standardized mortality rate was $4.9 / 100.000$ in 2013 [1].

Nearly $80 \%$ of the HNSCCs are ascribed to smoking and heavy alcohol use [2]. The first evidence of human papilloma virus (HPV) infection in head and neck carcinogenesis was provided already 35 years ago [3]. During the past 15 years, the research on HPV in HNSCC has been overwhelming, confirming that a subgroup of HNSCC is caused by HPV, especially HPV16. The HPVassociation is strongest for oropharyngeal cancers, yet highly variable worldwide [4]. Recently, the role of other viruses, e.g. HSV or EBV as co-factors for HPV-induced carcinogenesis has gained increasing interest, as discussed in a recent review [5].

Polyomaviruses (PyVs) resemble papillomaviruses in structural and functional properties, being small, nonenveloped, double-stranded, circular DNA viruses. The 
polyoma- and papillomaviruses were originally classified into the Papovaviridae family, which was split into the two families, papillomaviridea and polyomaviridae only in 2004 [6]. Up to now, 13 human polyomaviruses (HPyVs) have been identified. BKV was the first and JCV the second in this group, identified in 1971 [7, 8]. Primary infections with BKPyV occur mostly in childhood before the age of 7 years while the timing of primary JCV infection tends to be more common during the second and third decades of life, and are presumed to be subclinical with periodical virus shedding to urine and saliva [9-11]. While PyV-mediated diseases are known to occur mostly in immunocompromised patients, their role in human carcinogenesis - except for Merkel cell virus (MCPyV) [12] - is still controversial, and systematic studies on all the HPyVs known, with regard to cancers, are scanty (13-14).

BKPyV and JCPyV belong to the genus Betapolyomaviruses, together with the simian vacuolating virus 40 (SV40), discovered in 1960. SV40, one of the first tumor viruses described, might also circulate among humans although it is a non-human primate polyomavirus. It is estimated that over 100 million people may have been exposed to SV40 due to the contaminated polio vaccine administered during 1955-1963. Furthermore, it has been shown that polio vaccines produced from early 1960s to about 1978 from a major eastern European manufacturer were also SV-40 contaminated and widely used throughout the world [15]. The virus originated from the monkey kidney cell cultures used to produce the polio vaccine [16]. Shah and Nathanson 1976 [17] reported that intranasal administration of "old SV40 contaminated polio vaccine, SV40 produced a low grade infection with virus shedding in the respiratory tract and a low level antibody response in a few of the volunteers. Accordingly, several inhabitants in Finland also might have also been exposed to SV40 via this route in the late 1950's until 1964. The role of SV40 in human carcinogenesis has been widely discussed but the results have been conflicting. Shah in his mini review on SV40 and human cancer concluded that the most recent evidence does not support the notion that SV40 contributed to the development of human cancers [18]. SV40 has been shown to act as a coactivator of asbestos in mesothelial oncogenesis [19] although the detection rates of SV40 in mesothelioma show considerable variability. Thus, causal relationship between SV40 and this tumor cannot be drawn, yet [20].

The main oncogenic viral protein of SV40, JCPyV and $\mathrm{BKPyV}$ is the large tumor antigen (T-Ag) that is able to bind several host proteins, including retinoblastoma $(\mathrm{pRb})$ and $\mathrm{p} 53$. This will result in dysregulation of the cell cycling machinery as with the high-risk HPVs [13, 14]. Thus, SV40, JCPyV and BKPyV might be potential co-factors in HPV-induced carcinogenesis in the head and neck region. Both JCPyV and BKPyV can be detected in saliva even if their reservoir is unknown. There is evidence that tonsils, spleen, and lymph nodes are permissive to $\mathrm{JCV} / \mathrm{BKV}$, indicating that those tissues might have a role in viral persistence $[10,21,22]$. There are few reports on these viruses in HNSCCs but the numbers of cases analyzed have been limited and the results are conflicting [23-26].

The present study had three main aims; 1) to analyze the presence and SV40, JCV and BKV DNAs in HNSCCs and their impact on disease-specific survival (DSS), 2) to analyze the role of SV40, JCV and BKV as co-factors for HPV and some other herpesviruses previously analyzed in this same cohort, and 3) to study the presence of SV40, JCV and BKV DNAs in cell lines derived from HNSCCs. Moreover, we were interested in comparing the qPCRbased method for SV40, JCV and BKV DNA detection with a new multiplex method capable of detecting all 13 HPyVs known.

\section{RESULTS}

\section{HNSCCs}

The presence of SV40, JCV and BKV in HNSCCs $(n=82)$ was first analyzed with qPCR, all three viruses in separate $\mathrm{qPCR}$ reactions. Table 1 summarizes the prevalence of SV40, JCV and BKV as well as their copy numbers in the HNSCC samples, stratified by their anatomic sites. The most prevalent polyomavirus by far was JCV, found in $37 \%$ of the $81 \mathrm{HNSCC}$ (one sample missing due to lack of DNA). The carcinoma site most frequently associated with JCV was the lip (80\%), followed by the larynx $(66.7 \%)$, the oral cavity $(58.6 \%)$, the nasopharynx (33.3\%) and the hypopharynx (25\%). The copy numbers were highest in the larynx, yet varied widely among cancer sites (152514 mean copies/ $\mu \mathrm{g}$ $\mathrm{DNA}, \mathrm{SD} \pm 304820$ ). The highest copy number was in a laryngeal sample, 609,756 copies/ $\mu \mathrm{g}$ DNA pointing to an active viral replication. Overall, the average copy number levels in lip and oral cavity carcinomas were very similar (over 600 copies/ $\mu$ g DNA), but were markedly lower in nasopharyngeal and hypopharyngeal carcinomas; 156.8 and 122.3 copies/ $\mu$ g DNA, respectively. BKV was found in only one of the 29 oral cavity carcinomas, with 32.3 copies/ $\mu$ g DNA. SV40 DNA was found in three of the five lip carcinomas $(60 \%)$, and in $6 / 29$ oral cavity carcinomas $(20.7 \%)$. None of the pharyngeal samples tested SV40 positive, but two of the laryngeal carcinomas were positive $(28.6 \%)$. The copy numbers of SV40 in all anatomic sites were low, the means ranging from 6.6 to 23.7 copies $/ \mu \mathrm{g}$ DNA with an overall mean copies being only $12.4 \mathrm{copies} /$ ug. The copy numbers can be expressed also as copies per 1000 cells by estimating the DNA content of one diploid human cell to be $6 \mathrm{ng}$ meaning that there are only 74.4 copies of SV40 in 1000 cells. Interestingly, SV40, JCV or BKV were not found in any of the oropharyngeal carcinomas. 
Table 1: Prevalence of viral DNA of SV40, JCV and BKV and their DNA loads according to anatomical subsites of HNSCCs

\begin{tabular}{|c|c|c|c|c|c|c|}
\hline Location & $\begin{array}{c}\text { SV40+ } \\
\%\end{array}$ & $\begin{array}{c}\text { SV40 copy } \\
\text { numbers per } \mu \mathrm{g} \\
\text { DNA }(\text { Mean }+ \text { SD) }\end{array}$ & $\begin{array}{c}\text { JCV+ } \\
\%\end{array}$ & $\begin{array}{c}\text { JCV copy } \\
\text { numbers per } \mu \mathrm{g} \\
\text { DNA }(\text { Mean }+ \text { SD })\end{array}$ & $\begin{array}{c}\text { BKV+ } \\
\%\end{array}$ & $\begin{array}{c}\text { BKV copy } \\
\text { numbers per } \mu \mathrm{g} \\
\text { DNA }(\text { Mean }+ \text { SD })\end{array}$ \\
\hline Lip & $\begin{array}{c}3 / 5 \\
60.0 \%\end{array}$ & $\begin{array}{c}6.63 \\
(2.76)\end{array}$ & $\begin{array}{c}4 / 5 \\
80.0 \%\end{array}$ & $\begin{array}{c}702.23 \\
(1120.01)\end{array}$ & $\begin{array}{l}0 / 5 \\
0 \%\end{array}$ & - \\
\hline Oral Cavity & $\begin{array}{c}6 / 29 \\
20.7 \%\end{array}$ & $\begin{array}{c}11.52 \\
(10.26)\end{array}$ & $\begin{array}{c}17 / 29 \\
58.6 \%\end{array}$ & $\begin{array}{c}675.09 \\
(1126.14)\end{array}$ & $\begin{array}{l}1 / 29 \\
3.4 \%\end{array}$ & 32.27 \\
\hline Oropharynx & $\begin{array}{c}0 / 23 \\
0 \%\end{array}$ & - & $\begin{array}{c}0 / 23 \\
0 \%\end{array}$ & - & $\begin{array}{c}0 / 23 \\
0 \%\end{array}$ & - \\
\hline Nasopharynx & $\begin{array}{l}0 / 6 \\
0 \%\end{array}$ & - & $\begin{array}{c}2 / 6 \\
33.3 \%\end{array}$ & $\begin{array}{c}156.81 \\
(183.75)\end{array}$ & $\begin{array}{l}0 / 6 \\
0 \%\end{array}$ & - \\
\hline Hypopharynx & $\begin{array}{c}0 / 12 \\
0 \%\end{array}$ & - & $\begin{array}{c}3 / 12 \\
25.0 \%\end{array}$ & $\begin{array}{c}122.31 \\
(103.23)\end{array}$ & $\begin{array}{l}0 / 11 \\
0 \%\end{array}$ & - \\
\hline Larynx & $\begin{array}{c}2 / 7 \\
28.6 \%\end{array}$ & $23.74(29.23)$ & $\begin{array}{c}4 / 6 \\
66.7 \%\end{array}$ & $\begin{array}{c}152514.03 \\
(304820.00)\end{array}$ & $\begin{array}{l}0 / 6 \\
0 \%\end{array}$ & - \\
\hline $\begin{array}{l}\text { Total positivity and } \\
\text { overall mean copy } \\
\text { numbers per } \mu \mathrm{g} \text { DNA }\end{array}$ & $\begin{array}{c}11 / 71 \\
13.4 \%\end{array}$ & $\begin{array}{c}12.42 \\
(13.25)\end{array}$ & $\begin{array}{c}30 / 81 \\
37.0 \%\end{array}$ & $\begin{array}{c}20834.08 \\
(111233.62)\end{array}$ & $\begin{array}{c}1 / 81 \\
1.2 \%\end{array}$ & 32.27 \\
\hline
\end{tabular}

\section{Gender and HPyVs}

Women were significantly older than men at the time of diagnosis ( $\mathrm{p}=0.026$ ), with mean ages of 66.9 and 59.9 years, respectively. There was no gender association with JCV or SV40 detection. SV40 positive patients were slightly older than the negative ones, without statistical significance. JCV-positive patients were significantly older than JCVnegative patients (66.7 years vs. 59.3 years, $\mathrm{p}=0.017$ ).

\section{HNSCC survival}

The outcomes of the patients with JCV and SV40infected tumors are summarized in Figures 1 and 2. Neither SV40 nor JCV positivity showed any association with the patient's disease specific survival (DSS). There were no statistically significant differences in the copy numbers of SV40 or JCV according to the treatment mode (surgery or surgery and irradiation), TNM-classification or disease stage (I-IVA). However, the copies of SV40 were significantly lower in the patients without any metastasis to regional lymph nodes. None of the cancer patients had N2, while 4 of 11 patients had N1 disease with SV40 copies of $22.7 / \mu \mathrm{g}$ DNA. Seven of 11 SV40 positive patients had N0 with mean copy numbers of $6.5 /$ $\mu \mathrm{g}(\mathrm{p}=0.042)$.

\section{Co-infections with HPV or/and HSV-1}

Co-infections of polyomaviruses with HPV and/ or HSV-1 are presented according to age and gender in
Table 2. JCV infection was associated with HPV infection as $86.2 \%$ of the JCV positive HNSCC samples were also HPV positive ( $\mathrm{p}=0.001$ ). HPV was also present in $70 \%$ of the SV40 positive samples, but there was no statistically significant difference in HPV prevalence among the SV40 positive or negative samples. Only one sample was BKV positive and it also had a co-infection with both HPV and HSV-1. The co-infections of HPyV with HPV or HSV-1 alone or together did not affect the patient's DSS.

\section{UT-SCC cell lines}

Altogether, 23 cell lines were analyzed with qPCR. Only JCV was present in nine cell lines; all established from oral cavity cancers (Table 3 ). Seven were established from tongue and two from gingival carcinoma. Of the patients, six were women and three were men. The histology of the original tumors of the nine JCV-positive cell lines was well differentiated SCC in five cases, moderately differentiated in three, and poorly differentiated in one. Three of the patients had presented with regional neck metastases, yet none with distant metastases. JCV copy numbers ranged from 213.8 to 444.2 copies per $\mu \mathrm{g}$ DNA with an average of 86.9 copies.

\section{Comparison of the qPCR and Multiplex methods}

Comparison of the two methods was done by using the DNAs extracted from 42 HNSCC samples and 23 cell lines. Table 4 summarizes the concordance of the JCV results. Of the 42 tested HSCC samples 23 (54.8\%) 


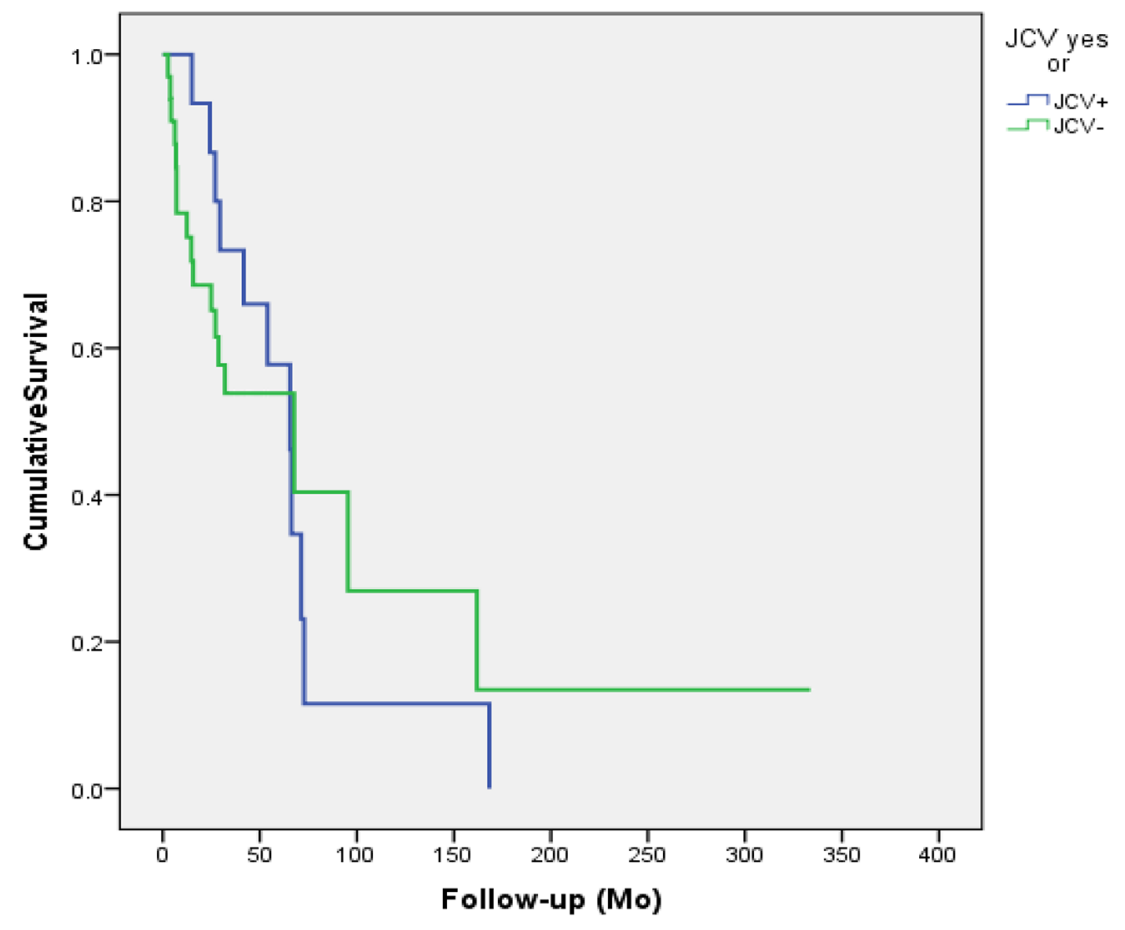

Figure 1: Disease specific survival of the patients accroding to the JCV status in the cancer tissue. JCV had no efect on the outcome of the patient $(\mathrm{p}=0.914)$.

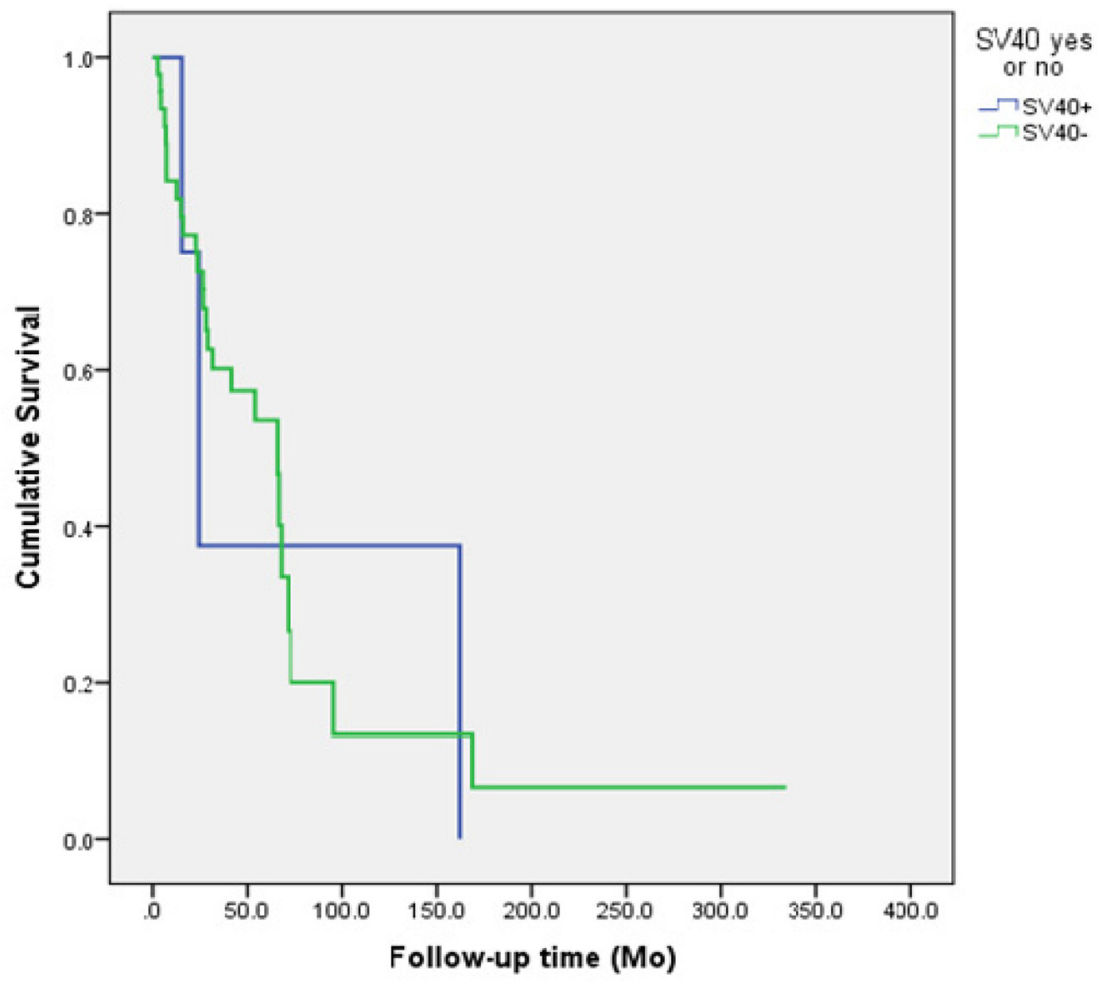

Figure 2: The survival of the patients according to the SV40 status of the head and neck cancer. The presence of SV40 had no effect on the patient's survival $(\mathrm{p}=0.894)$. 
Table 2: Prevalence of JCV, SV40 and BKV according to patient age and gender and co-infections with HPV and/or HSV-1

\begin{tabular}{|c|c|c|c|c|c|c|}
\hline & \multicolumn{2}{|c|}{$\mathrm{JCV}(\mathrm{N}=\mathbf{8 1})$} & \multicolumn{2}{|c|}{ SV40 } & \multicolumn{2}{|c|}{ BKV } \\
\hline & $\mathrm{JCV}+(\mathrm{N}=\mathbf{3 0})$ & $\mathrm{JCV}-(\mathrm{N}=51)$ & $\mathrm{SV40}+(\mathrm{N}=11)$ & SV40- $(N=71)$ & $\mathrm{BKV}+(\mathrm{N}=\mathbf{1})$ & BKV- $(\mathbf{N}=\mathbf{8 0})$ \\
\hline Mean age (years) & 66.7 & 59.3 & 65.9 & 61.7 & 76 & 61.9 \\
\hline $\begin{array}{l}\text { Gender } \\
\text { men } \\
\text { women }\end{array}$ & $\begin{array}{l}17 / 53(32.1 \%) \\
13 / 28(46.4 \%)\end{array}$ & $\begin{array}{l}36 / 53(67.9 \%) \\
15 / 28(53.6 \%)\end{array}$ & $\begin{array}{l}6 / 54(11.1 \%) \\
5 / 28(17.9 \%)\end{array}$ & & $\begin{array}{l}0 / 53 \\
1 / 28\end{array}$ & $\begin{array}{l}53 / 53 \\
27 / 28\end{array}$ \\
\hline $\begin{array}{l}\mathrm{HPV}+{ }^{*} \\
\mathrm{HPV}-\end{array}$ & $\begin{array}{c}25 / 29(86.2 \%) \\
4 / 29(13.8 \%)\end{array}$ & $\begin{array}{l}25 / 51(49.0 \%) \\
26 / 51(51.0 \%)\end{array}$ & $\begin{array}{l}7 / 10(70.0 \%) \\
3 / 10(30.0 \%)\end{array}$ & $\begin{array}{l}43 / 71(60.6 \%) \\
28 / 71(39.4 \%)\end{array}$ & $\begin{array}{l}1 / 1 \\
0 / 1\end{array}$ & \\
\hline $\begin{array}{l}\text { HSV-1+ } \\
\text { HSV-1- }\end{array}$ & $\begin{array}{c}0 / 19(0.0 \%) \\
19 / 19(100 \%)\end{array}$ & $\begin{array}{c}3 / 41(7.3 \%) \\
38 / 41(92.7 \%)\end{array}$ & $\begin{array}{l}0 / 7(0.0 \%) \\
7 / 7(100 \%)\end{array}$ & $\begin{array}{c}3 / 54(5.6 \%) \\
51 / 54(94.4 \%)\end{array}$ & $\begin{array}{l}1 / 1 \\
0 / 1\end{array}$ & \\
\hline $\mathrm{HPV}+\& \mathrm{HHV}-1+$ & $0 / 19(0.0 \%)$ & $3 / 41(7.3 \%)$ & $0 / 7(0.0 \%)$ & $3 / 54(5.6 \%)$ & $1 / 1$ & $2(3)$ \\
\hline
\end{tabular}

*The HPV DNA positivity was statistically significantly associated with the JCV positivity $(\mathrm{p}=0.001)$.

Table 3: Characteristics of the original tumors of the JCV DNA positive cell lines

\begin{tabular}{|c|c|c|c|c|c|c|}
\hline Cell line & $\begin{array}{c}\text { JCV copy numbers } \\
\text { per } \mu \text { g DNA }\end{array}$ & Origin on the cell line & TNM & Grade & Gender & Age years \\
\hline UT-SCC-16A & 30.3 & tongue & T3N0M0 & G3 & woman & 77 \\
\hline UT-SCC-30 & 17.1 & tongue & T3N1M0 & G1 & woman & 77 \\
\hline UT-SCC-40 & 10.7 & tongue & T3N0M0 & G1 & woman & 65 \\
\hline UT-SCC-43A & 35.8 & gingiva mandible & T4N1M0 & $\mathrm{G} 2$ & woman & 75 \\
\hline UT-SCC-55 & 19.3 & gingiva mandible & T4N1M0 & G2 & $\operatorname{man}$ & 76 \\
\hline UT-SCC-81 & 13.4 & tongue & T2N0M0 & G1 & $\operatorname{man}$ & 48 \\
\hline UT-SCC-92 & 17.7 & tongue & T2N0M0 & G1 & woman & 57 \\
\hline UT-SCC-95 & 19.9 & tongue & T1N0M0 & G1 & woman & 83 \\
\hline UT-SCC-97 & 64.2 & tongue & T2N0M0 & $\mathrm{G} 2$ & man & 67 \\
\hline
\end{tabular}

Cell lines with bold letters tested JCV positive also with Multiplex test.

Table 4: Comparison of the qPCR and Multiplex methods in detecting of JCV

\begin{tabular}{|c|c|c|c|c|c|}
\hline & \multirow{2}{*}{\multicolumn{2}{|c|}{ JCV detection with qPCR }} & \multicolumn{2}{|c|}{$\begin{array}{l}\text { JCV detection with } \\
\text { Multiplex method }\end{array}$} & \multirow[t]{2}{*}{ Total } \\
\hline & & & $\mathbf{J C V +}$ & JCV- & \\
\hline \multirow[t]{4}{*}{ JCV yes or no } & $\mathrm{JCV}+$ & $\mathrm{N}$ & 21 & 5 & 26 \\
\hline & & $\begin{array}{c}\% \text { with JCV yes or } \\
\text { no }\end{array}$ & $80.8 \%$ & $19.2 \%$ & $100.0 \%$ \\
\hline & $\mathrm{JCV}-$ & $\mathrm{N}$ & 2 & 14 & 16 \\
\hline & & $\begin{array}{c}\% \text { with JCV yes or } \\
\text { no }\end{array}$ & $12.5 \%$ & $87.5 \%$ & $100.0 \%$ \\
\hline \multirow[t]{2}{*}{ Total } & & $\mathrm{N}$ & 23 & 19 & 42 \\
\hline & & $\begin{array}{l}\% \text { with JCV } \\
\text { yes or no }\end{array}$ & $54.8 \%$ & $45.2 \%$ & $100.0 \%$ \\
\hline
\end{tabular}


Table 5: Primers and probes for SV40, JCV and BKV detection with qPCR

\begin{tabular}{ll}
\hline Name & Sequence Detection \\
\hline SV40 primer forward & GAT GGC ATT TCT TCT GAG CAA A \\
SV40 primer reverse & GAA TGG GAG CAG TGG TGG AA \\
JCV primer forward & TTC TTC ATG GCA AAA CAG GTC TT \\
JCV primer reverse & GAA TGG GAA TCC TGG TGG AA \\
BKV primer forward & CTT TCT TTT TTT TTT GGG TGG TGT T \\
BKV primer reverse & TTG CCA GTG ATG AAG AAG CAA \\
SV40 T-ag probe 5'-FAM & CAG GTT TTC CTC ATTAAA \\
JCV T-ag probe 5' FAM & CCA CTT CTC ATT AAA TG \\
BKV T-ag probe 5' FAM & AGT GTT GAG AAT CTG C \\
\hline
\end{tabular}

Adapted from McNees et al., 2005 [41].

and $19(45.2 \%)$ were JCV positive and negative with the Multiplex method, respectively. qPCR found JCV in $21(91.3 \%)$ of the 23 Multiplex positive samples. In all, the results were concordantly JCV-negative in $74.7 \%$ of the cases (14/19). The overall concordance between the two methods in detecting JCV was statistically highly significant $(\mathrm{p}=0.0001)$ with a kappa value of 0.659 .

With the Multiplex method, four HNSCC samples tested positive for MCPyV, and one sample for HPyV6. All the MCPyV positive samples were also JCV positive. Of these two were women and two men, with respective age ranges of 60-76 and 51-95 years. The carcinomas were located in the lip, maxillary sinus, and tongue (two). Interestingly, the woman with maxillary carcinoma had also been diagnosed with skin carcinoma of the upper lip at the age of 42 years. The HPyV6 positive sample was derived from a female with laryngeal and base of the tongue cancer.

\section{Cell lines}

In the cell lines the Multiplex method gave positive results exclusively for $\mathrm{JCV}$, as also did the qPCR. Of the nine qPCR-positive cell lines, four (UT-SCC-16A, UTSCC-81, UT-SSC-95 and UT-SCC-97) tested positive with the Multiplex method (Table 3). These cell lines were all derived from the tongue carcinomas.

\section{DISCUSSION}

This study confirmed that polyomaviruses are detectable in head and neck cancers. JCV was the most frequent $(37 \%)$ in the HNSCCs, followed by SV40 in $13.4 \%$ and BKV in $1.2 \%$. Only few previous studies are available providing evidence that carcinomas of the tongue, pharynx and larynx might be associated with PyVs [23, 25-27].

All oropharyngeal carcinomas remained $\mathrm{PyV}$ negative in our study unlike in that of Zheng and coworkers [27]. They reported significantly higher copy numbers in carcinomas of the mobile tongue and pharynx than in the respective healthy mucosa. Contradictory to oropharyngeal carcinomas, we were able to detect JCV DNA in 2/6 and 3/12 naso- and hypopharyngeal carcinomas, respectively. In our study, the most prevalent sites for JCV and SV40-associated HNSCC, independently, were larynx followed by lip and oral cavity. According to Zheng and coworkers [27], there was no significant difference in the prevalence of JCV DNA in normal laryngeal mucosa and in laryngeal carcinoma.

Kutsuna et al. [23] reported a connection between high JCV viral load and tongue carcinomas, in line with our observations. They demonstrated JCV viral loads of more than 200 copies/ $\mu \mathrm{g}$ in 36 of the 39 tongue carcinoma samples analyzed. Of these, 15 contained more than 1000 copies/ $\mu$ g DNA. Accordingly, they concluded that JCV might be a risk factor for tongue carcinogenesis. Our data do support this hypothesis, with JCV DNA demonstrated in $58.6 \%(17 / 29)$ of oral cavity carcinomas, even the copy numbers we found were lower. More importantly, we showed that of the JCV-positive cell lines derived originally from oral cavity carcinomas, seven originated actually from tongue. This indicates that tongue might have a particular predilection for transforming JCV infections. The copy numbers in oral carcinoma samples (675 mean copies/ $\mu \mathrm{g}$ DNA) were higher than in the cell lines ( 25 copies/ $\mu \mathrm{g}$ DNA). Unfortunately, we did not have any of the original tumors of these cell lines available for polyomavirus testing. However, based on our previous studies on HPV, it was shown that viral genome can disappear in the early passages of cell cultivation [28]. This also supports the concept of hetero-population and cell selection, in line with the hit and run hypothesis.

The JCV copy numbers especially in laryngeal carcinomas were high. However, the number of cases analyzed was small and the ranges in copy numbers high. These observations warrant further studies on the association of JCV in laryngeal carcinogenesis, even if none of the laryngeal cancer cell lines tested JCV positive. 
Nearly $14 \%$ of the HNSCC samples studied contained SV40 DNA, but the copy numbers were low. Contradictory to our results, Palmieri and coworkers [29] did not find any SV40 in oral samples derived from either healthy tissue or cancer. SV40 is not originally hosted by humans but by monkeys and it has entered the human population mainly via contaminated polio vaccines in the 1950 's and early 1960's [16, 30]. According the review by Shah (18) SV40 seroreactivity in cancer cases and controls varied from $2.5 \%$ to $15.2 \%$ and from $2.9 \%$ to $10.5 \%$, respectively. This indicates that immunoreactivity to SV 40 is found but the frequency of seropositivity is nearly the same in the cases and the controls, similarly as recently reported by Antonsson et al. [31] even the seroprevalence of BKV, JCV and SV40 in the controls, they found, was much higher, $89 \%, 48 \%$ and $21 \%$, respectively. A recent study showed SV40-specific serum antibodies detectable in pregnant women at the time of delivery and in cord blood; yet with no evidence of trans-placental transmission of SV40. These data suggest that SV40 is still circulating at low prevalence long after use of the contaminated vaccine. [32]. SV40 has also been found in tonsils of immunocompetent children. It seems likely that the oropharyngeal lymphatics may be able to host DNA virus persistence [10, 24, 33, 34]. Thus, SV40 known to be able to transform also oral keratinocytes advocates further studies on its role in head and neck carcinogenesis.

Both BKV and JCV are ubiquitous viruses, and up to $80 \%$ of the adult population is seropositive for both $[35,36]$. Given that we did not have any biopsies from normal head and neck mucosa, one can always argue the specificity of our findings. Previous studies have shown that polyomaviruses, especially JCV and SV40, can infect B-cells and even establish a latency in these cells. Accordingly, oropharyngeal carcinomas would be the most likely samples to test polyomavirus-positive due to their abundance of B-cells. However, in the present analysis, all oropharyngeal cancers remained negative for JCV, BKV and SV40 providing indirect evidence against these viruses being present in lymphocytes of the tumor tissues.

In this context, a reference is made to the report of Palmier and coworkers [29], who studied 294 tumor samples (paraffin embedded) and 237 matched controls from oral cavity for the presence of $\mathrm{BKV}, \mathrm{JCV}$ and SV40, using qPCR. They found only one BKV-positive tumor among all 483 samples including both the tumors and the controls. However, the viral load was very low; only 0.18 viral genome per cell. Furthermore, 15 tumor samples and 18 controls showed some PCR endpoint signals for the presence of BKV. These samples were also classified as negative as they did not reach the threshold of 1.0 viral genome per cell. If we estimate that there are nearly 100,000 carcinoma cells in one $\mu \mathrm{g}$ of DNA, only a few samples from the lip, oral cavity and laryngeal carcinomas would have been signed as JCV-positive in our study. However, we can argue this approach because our samples were examined also with a novel, somewhat less sensitive Multiplex method [37]. Altogether, 91\% of the 23 samples testing JCV-positive with Multiplex were positive also with the qPCR. Furthermore, $74 \%$ of the multiplex-negative samples were also negative with the qPCR. Four of the cell lines tested positive with both methods. Thus, the overall concordance between the two methods was excellent indicating that the PyV findings achieved with qPCR correctly reflect the presence of viral DNA in the tumours and corresponding cell lines.

In the present series, the PyV-positive patients were slightly older than the virus-negative ones, yet the difference was significant only with JCV. Zeng et al. [27] did not find any effect of age on JCV viral loads. Polz and coworkers [25] showed an age association in BKVpositive oral cancer. Zheng et al. [27] also reported that JCV load was unrelated to tumor grade, consistent with our data. The same was reported by Polz et al. [25] with regard to oral cancer and BKV positivity.

In addition to their independent oncogenic role, also an auxiliary cancer-driving role of HPyV infections in combination with HPV infections deserves some consideration $[13,26]$. SV40 was shown to increase the transforming activity of HPV16 by 10 - to 15 -fold in vitro [38]. A recent review showed that co-infections of HPyV and oncogenic HPVs are not infrequent [39]. This is particularly true in anal cancer and high-grade cervical intraepithelial lesions (CIN) [40]. In the present study, both SV40 and JCV were frequently found in concert with HPV. Interestingly, no particular HPV genotype preferentially escorted JCV. No previous studies exist on JCV/HPV or SV40/HPV coinfections in HNSCC. Comar and coworkers [32] reported $\mathrm{JCV}$ in $7 \%$ of the high-grade CIN but not in normal cervical samples. Alosaimi et al. [40] found 3-fold higher JCV frequency in cervical cancers than in normal cervical smears among HIV-positive women. This suggests a role of JCV in cervical cancer in HIV-co-infected, immunosuppressed patients. Polz-Gruszka [26] and coworkers found that 4.8\% of the oropharyngeal cancers exhibited HPV/BKV coinfection. We found only one sample with HPV/BKV coinfection, not derived from oropharynx. The presence of JCV, BKV or SV40 either alone or with HPV-co-infection did not affect disease specific survival (DSS), as expected. Our cohort did not raise any oropharyngeal cancer type above others in predisposition to HPV/HPyV co-infection. HPV is known to be associated with a better survival, especially if the patient has never smoked or has no other comorbidity [41, 42].

When detecting polyomaviruses, JCV, BKV and SV40, with PCR or qPCR a remark has to make on the possibility of the crossreactivity due to the sequence homology. We have used qPCR using the method described by McNees et al. 2005 (43). Based on their carefully controlled study quantification of the target genes was sensitive and specific over a $7 \log$ dynamic range. Ten copies each of the viral and cellular genes were reproducibly and accurately detected. The primers and probes used to detect the viral genes were specific for each 
virus and there was no cross reactivity within the dynamic range of the standard dilutions as we also showed in our experiments. The sensitivity of detection for these assays was not reduced in human cellular extracts. SV40 plasmid has never been available in our laboratory omitting the possibility of plasmid contamination which has been blamed for false positive results at low copy numbers.

To conclude, our results showed that JCV was found in HNSCC and also SV40 but the latter at very low copy numbers. Like BKV, both of these viruses have been implicated in human oncogenesis. Head and neck region is an important area to explore virus-related cancers. Epithelial cells of head and neck mucosa are continuously exposed to DNA-damaging agents, resulting in cellular responses that induce cell-cycle arrest or apoptosis to allow repair or elimination of the damaged cell. PyVs have several mechanisms to promote cellular proliferation and efficiently replicate their own DNA even in the presence of cellular stress. T-antigen is the main oncogenic protein of JCV, BKV and SV40. It can inactivate p53 and the members of pRb family, resulting in deregulation of cell cycle checkpoints and elimination of p53-mediated pro-apoptotic activity similarly as done by high-risk HPVs. Additionally, T-antigen exerts its oncogenic activity by deregulating the Wnt signaling pathway through stabilization of $\beta$-catenin and its interaction with the IGF-IR signaling system for cellular transformation. The $\mathrm{Wnt} / \beta$-catenin signaling pathway has also been noted to be upregulated in HNSCC [44]. Thus, further studies are needed to understand the role of PyVs in HNSCC either as independent infections or co-infections with other oncogenic viruses like HPV and EBV.

\section{MATERIALS AND METHODS}

\section{Patients and HNSCC samples}

This study consists of 82 patients with primary HNSCCs. Of them 54 were men and 28 women with a mean age of 62.3 years ( \pm SD 13.7 years) and a range from 27 to 96 years. All patients were treated with curative intent at Turku University Hospital between 19882015, where the management of all HNSCC patients is centralized from South-Western Finland, Ahvenanmaa and Satakunta. The tumor samples were obtained during the primary surgery (for temporary or permanent treatment) or as biopsies. The samples were freshly frozen in liquid nitrogen and stored at $-70^{\circ} \mathrm{C}$ until use. Only samples histologically representing the original tumors were included in the study. Clinical data were collected retrospectively from the hospital records. The study has been approved by the Ethical Committee of the Hospital District of South-Western Finland (4/2009).

\section{Cell lines}

Altogether, 23 UT-SCC (University of Turku squamous cell carcinoma) cell lines established from
HNSCCs as described earlier were available for the present study [45]. The cells were cultured in Dulbecco's minimal essential medium (D-MEM, Paisley, UK), supplemented with $1 \%$ non-essential amino acids, $2 \mathrm{mM}$ L-glutamine, $50 \mathrm{mg} / \mathrm{ml}$ streptomycin, $100 \mathrm{U} / \mathrm{ml}$ penicillin and $10 \%$ fetal calf serum, in $75 \mathrm{~mm}^{3}$ bottles. The cell lines were harvested at $80 \%$ confluence.

\section{DNA extraction}

\section{Biopsy samples}

HPV DNA was extracted with the high salt method [46]. In brief, the samples were lysed in lysis buffer (10mMTris- $\mathrm{HCl}, 400 \mathrm{mMNaCl}$ and $2 \mathrm{mM}$ EDTA, $\mathrm{pH}$ 8.2) with proteinase $\mathrm{K}$. After digestion, proteins were precipitated with saturated $\mathrm{NaCl}$ and DNA with ethanol.

\section{Cell lines}

The cell pellet was suspended in $50 \mu \mathrm{l}$ of extraction solution prepared by combining $0.5 \mathrm{M}$ EDTA $\mathrm{pH} 8.0$, $1 \mathrm{M}$ Tris $\mathrm{pH} 8.0$, Tween-20, Proteinase $\mathrm{K}$ at $20 \mathrm{mg} / \mathrm{ml}$ and ultrapure water. The tubes were incubated at $37^{\circ} \mathrm{C}$ overnight after which the proteinase $\mathrm{K}$ was inactivated by heating to $95^{\circ} \mathrm{C}$ for $10 \mathrm{~min}$. After digestion, proteins were precipitated with saturated $\mathrm{NaCl}$ and DNA with ethanol.

\section{HPV and HSV DNA detection}

The presence of HPV and HSV-1, in these tumors has been reported earlier [47]. For HPV detection and genotyping, nested PCR (MY09/MY11 as external primers and GP05+/bioGP06+-as internal primers) and Luminexbased Multimetrix ${ }^{\circledR}$ kit (Progen Biotechnik GmbH, Heidelberg, Germany) was used. The kit detects $24 \mathrm{HPV}$ genotypes (low risk types 6/11/42/43/44/70 and high risk types 16/18/30/31/33/35/39/45/51/52/53/56/58/59/66/68/ 73/82) [48]. HSV-1 was detected with PCR and Luminex xMAP technology, as decribed earlier [48].

\section{HPyV detection with qPCR}

SV40, JCV and BKV DNAs were detected by qPCR (Roche, Light Cycler 96, (Roche Diagnostics, Roche Molecular Diagnostics, Pleasanton, CA, USA) targeting their oncogenic large $\mathrm{T}$ antigen (T-ag) as decribed earlier ref [43]. TaqMan ${ }^{\circledR}$ Copy Number Reference Assay RNase was used as a reference gene (Applied Biosystems, 4403328). Table 5 summarizes the oligonucleotide sequences of the primers and probes used in qPCR as described by McNees et al. in 2005 [43]. The probes for the target genes SV40, JCV and BKV were labeled with 6-carboxyfluorescein (FAM), and for the reference gene RNase P, with 4,7,2'-trichloro-7'-phenyl6-carboxyfluorescein (VIC). The oligonucleotides were provided by Applied Biosystems (Foster City, CA, USA). The primers were reconstituted in sterile water and the primers and probes were aliquoted and stored at $-20{ }^{\circ} \mathrm{C}$ in small volumes to minimize multiple uses of these reagents. 
Using either strip tubes or 96-well plates (Roche LightCycler $^{\circledR}$ 96), and caps or adhesive covers of optical grade (Roche), $20 \mu \mathrm{l}$ PCR reactions were prepared for SV40, JCV or BKV separately containing $900 \mathrm{nM}$ of each primer, $100 \mathrm{nM}$ of FAM-labeled probe, and $25 \mu \mathrm{l}$ of $2 \times$ TaqMan Universal PCR Master Mix (Applied Biosystems). For detection of the cellular gene, primer and probe components of the TaqMan RNAse P Control reagents (VIC dye) (Applied Biosystems) were used according to the manufacturer's instructions using the TaqMan Universal PCR Master Mix. Two microliters of standard plasmid dilutions or positive control samples or test DNA samples was added in duplicate outside the core facility after the tubes containing the master mix and negative controls were sealed. qPCR reaction conditions for amplification of all target genes were as follows: $50^{\circ} \mathrm{C}$ for $2 \mathrm{~min}$, denaturing at $95^{\circ} \mathrm{C}$ for $10 \mathrm{~min}$, and 45 cycles of denaturing at $95^{\circ} \mathrm{C}$ for $15 \mathrm{~s}$ followed by annealing and extension at $60^{\circ} \mathrm{C}$ for $1 \mathrm{~min}$. Amplification data measured as an increase in reporter fluorescence were collected in real time and analyzed by the LightCycler ${ }^{\circledR} 96$ Application and Instrument Software Sequence Detection (Roche Diagnostics, Indianapolis, US).

The linear standard curves for JCV and BKV were obtained with a serial dilution of plasmids ranging from $1.2^{*} 10^{\wedge} 0$ to $1.2^{*} 10^{\wedge}-2 \mathrm{ng} / \mu \mathrm{l}$ for $\mathrm{JCV}$ and $9.5^{*} 10^{\wedge} 0$ to $9.5^{*} 10^{\wedge}-3 \mathrm{ng} / \mu \mathrm{l}$ for $\mathrm{BKV}$. COS1 cell line containing one copy of SV40 was used for SV40 standards using a dilution of DNA from $5.0^{*} 10^{\wedge} 4$ to $5.0^{*} 10^{\wedge} 0$ cells $/ \mu 1$, while the standards for the reference gene RNase $\mathrm{P}$ was acquired with a serial dilution of human placenta DNA extractions ranging from $5.09^{*} 10^{\wedge} 2$ to $5.09^{*} 10^{\wedge}-2$ (Sigma-Aldrich, St. Louis, MO, USA).

The primers and probes used to detect the viral genes were specific for each virus and there was no cross reactivity within the dynamic range of the standard dilutions.

\section{Multiplex PCR for HPyV detection using the Luminex platform}

All the HPyV assays were performed as recently described by Sadeghi and coworkers [37]. In brief, $5 \mu \mathrm{l}$ DNA template was combined with $20 \mu$ multiplex reaction consisting of $12.5 \mu \mathrm{l}$ of $2 \mathrm{x}$ multiplex PCR mastermix (Qiagen), $0.2 \mu \mathrm{M}$ of each forward primer and $1 \mu \mathrm{M}$ of each biotinylated reverse primer. The amplification conditions were $95^{\circ} \mathrm{C}$ for $15 \mathrm{~min}, 40$ cycles at $94^{\circ} \mathrm{C}$ for $20 \mathrm{~s}, 50^{\circ} \mathrm{C}$ for $90 \mathrm{~s}, 71^{\circ} \mathrm{C}$ for $1 \mathrm{~min}$ and $20 \mathrm{~s}$, and a final extension at $71^{\circ} \mathrm{C}$ for $10 \mathrm{~min}$.

Luminex-based suspension array procedure (oligonucleotide coupling, hybridization, and measurement) were as described by in [30]. In brief, the 5' amine C-12 modified oligonucleotide probes were coupled to a variety of carboxylated fluorescent microbeads (Luminex Corp., The Netherlands) according to the manufacturer's instructions (xMAP cookbook, Luminex). The probe-coupled beads were counted using a hemocytometer, and stored in the dark at $+4^{\circ} \mathrm{C}$. $45 \mu \mathrm{l}$ of probe-bead mix combined with $5 \mu \mathrm{l}$ of
PCR products were hybridized for 40 minutes at $48^{\circ} \mathrm{C}$, and incubated with streptavidin-phycoerythrin for 20 minutes at hybridization temperature. Measurement: after three washes, the signals of the beads and SAPE were measured in a BioPlex 200 (Bio-Rad).

\section{Statistical analysis}

For categorical variables, the frequency tables were analyzed using the $\chi 2$-test, interpreted with the likelihood ratio (LR) or Fisher's exact statistics. Odds ratios (OR) and their 95\% confidence intervals (95\% CI) were calculated where appropriate, using the exact method. Differences in means of continuous variables were analyzed using Mann-Whitney's or Kruskal-Wallis's test for two and multiple independent samples, respectively. Univariate survival analysis for outcome measures (DSS) was based on Kaplan-Meier method, in which stratumspecific estimates were compared using the log-rank (Mantel-Cox) statistics. Only the patients treated with curative intent were taken into consideration in these survival calculations. All statistical tests were performed as two-sided and considered significant at p-value $<0.05$. Statistical analyses were run, using SPSS $®$ 23.0.0.0 (SPSS, Inc., Chicago, USA) and STATA/SE 11.1 (STATA Corp., College Station, TX, USA) software packages.

\section{Abbreviations}

DNA, deoxyribonucleic acid; DSS, disease specific survival; EBV, Ebstein Barr virus; FAM, 6-carboxyfluorescein; HNSCC, head and neck squamous cell carcinoma; HPV, human papillomavirus; HPyV, human polyomavirus; HSV, herpes simplex virus; LR, likelihood ratio; OR, odds ratios; $\mathrm{pRb}$, retinoblastoma; $\mathrm{PyV}$, polyomavirus; qPCR, quantitative polymerase chain reaction; SCC, squamous cell carcinoma; VIC 4,7,2'-trichloro-7'-phenyl-6-carboxyfluorescein.

\section{Author contributions}

Conception and design: SS, KH

Acquisition of data: RG, JR, LP

Analysis and interpretation of data: All authors

Writing, review, and or revision of the manuscript: All authors.

\section{ACKNOWLEDGMENTS}

The authors thank the skillful technical assistance of Tatjana Peskova, Paula Väyrynen and Mariia Valkama.

\section{CONFLICTS OF INTEREST}

The authors declare no conflicts of interest. 


\section{FUNDING}

This study was funded by the Department of Oral Pathology, Institute of Dentistry, Faculty of Medicine, University of Turku. The study (of Y.W. and K.H.) was supported by the Sigrid Jusélius Foundation, the Jane and Aatos Erkko Foundation, the Helsinki University Hospital Research and Education Fund, and The Medical Society of Finland (FLS).

\section{REFERENCES}

1. International Agency of Research of Cancer. IARC Monogr Eval Carcinog Risks Hum. 2012; 100B:274-76.

2. Hashibe M, Brennan P, Benhamou S, Castellsaque X, Chen C, Curado MP, Dal Maso L, Daudt AW, Fabianova E, Fernandez L, Wunsch-Filho V, Franceschi S, Hayes RB, et al. Alcohol drinking in never users of tobacco, cigarette smoking in never drinkers, and the risk of head and neck cancer: pooled analysis in the international head and neck cancer epidemiology consortium. J Natl Cancer Inst. 2007; 99:777-789.

3. Syrjänen K, Syrjänen S, Lamberg M, Pyrhönen S, Nuutinen J. Morphological and immunohistochemical evidence suggesting human papillomavirus (HPV) involvement in oral squamous cell carcinogenesis. Int J Oral Surg. 1983; 12:418-424.

4. Ndiaye C, Mean M, Alemany L, Arbyn M, Castellsaque X, Laporte L, Bosch FX, de Sanjose S, Trottier H. HPV DNA, E6/E7 mRNA, and p16INK4a detection in head and neck cancers: a systematic review and meta-analysis. Lancet Oncol. 2014; 15:1319-1331.

5. Guidry JT, Scott RS. The interaction between human papillomavirus and other viruses. Virus Res. 2017; 231:139-147.

6. de Villiers EM, Fauquet C, Broker TR, Bernard HU, zur Hausen H. Classification of papillomaviruses. Virology. 2004; 324:17-27.

7. Gardner SD, Field AM, Coleman DV, Hulme B. New human papovavirus (B.K.) isolated from urine after renal transplantation. Lancet. 1971; 1:1253-7.

8. Padgett BL, Walker DL, Zu Rhein GM, Eckroade RJ, Dessel BH. Cultivation of papova-like virus from human brain with progressive multifocal leucoencephalopathy. Lancet. 1971; 1:1257-1260.

9. Egli A, Infanti L, Dumoulin A, Buser A, Samaridis J, Stebler C, Gosert R, Hirsch HH. Prevalence of polyomavirus BK and JC infection and replication in 400 healthy blood donors. J Infect Dis. 2009; 199:837-46.

10. Comar M, Zanotta N, Bovenzi M, Campello C. JCV/ BKV and SV40 viral load in lymphoid tissues of young immunocompetent children from an area of north-east Italy. J Med Virol. 2010; 82:1236-1240.
11. Vanchiere JA, White ZS, Butel JS. Detection of BK virus and simian virus 40 in the urine of healthy children. J Med Virol. 2005; 75:447-454.

12. Feng H, Shuda M, Chang Y, Moore PS. Clonal intergration of a polyomavirus in human Merker cell carcinoma. Science. 2008; 319:1096-100.

13. Moens U, Van Ghelue M, Ehlers B. Are human polyomaviruses co-factors for cancers induced by other oncoviruses. Rev Med Virol. 2014; 24:343-60.

14. Delbue S, Comar M, Ferrante P. Review on the role of the human Polyomavirus JC in the development of tumors. Infect Agent Cancer. 2017; 12:10.

15. Cutrone R, Lednicky J, Dunn G, Rizzo P, Bocchetta M, Chumakov K, Minor P, Carbone M. Some oral poliovirus vaccines were contaminated with infectious SV40 after 1961. Cancer Res. 2005; 65:10273-9.

16. Stratton K, Almario DA, McCormick MC, editors. Immunization safety review. SV40 contamination of polio vaccine and cancer. Washington, DC, US: National Academies Press. 2002.

17. Shah K, Nathanson N. Human exposure to SV40: review and comment. Am J Epidemiol. 1976; 103:1-12.

18. Shah KV. SV40 and human cancer: a review of recent data. Int J Cancer. 2007; 120:215-223.

19. Jaurand MC, Fleury-Feith J. Pathogenesis of malignant pleural mesothelioma. Respirology. 2005; 10:2-8.

20. Attanoos RL, Churg A, Galateau-Salle F, Gibbs AR, Roggli VL. Malignant mesothelioma and its non-asbestos causes. Arch Pathol Lab Med. 2018 Feb 26. [Epub ahead of print].

21. Monaco MC, Jensen PN, Hou J, Durham LC, Major EO. Detection of JC virus DNA in human tonsil tissue: evidence for site of initial viral infection. J Virol. 1998; 72:9918-9923.

22. Kato A, Kitamura T, Takasaka T, Tominaga T, Ishikawa A, Zheng HY, Yogo Y. Detection of the archetypal regulatory region of JC virus from the tonsil tissue of patients with tonsillitis and tonsilar hypertrophy. J Neurovirol. 2004; 10:244-249.

23. Kutsuna T, Zheng H, Abdel-Aziz HO, Murai Y, Tsuneyama K, Furuta I, Takano Y. High JC virus load in tongue carcinomas may be a risk factor for tongue tumorigenesis. Virchows Arch. 2008; 452:405-410.

24. Patel NC, Vilchez RA, Killen DE, Zanwar P, Stroller V, Eldin KW, Lopez-Terrada D, Butel JS. Detection of polyomavirus SV40 in tonsils from immunocompetent children. J Clin Virol. 2008; 43:66-72.

25. Polz D, Morshed K, Stec A, Podsiadło Ł, Polz-Dacewicz M. Do polyomavirus hominis strains BK and JC play a role in oral squamous cell carcinoma? Ann Agric Environ Med. 2015; 22:106-109.

26. Polz-Gruszka D, Morshed K, Jarzyński A, PolzDacewicz M. Prevalence of Polyoma BK Virus (BKPyV), 
Epstein-Barr Virus (EBV) and Human Papilloma Virus (HPV) in Oropharyngeal Cancer. Pol J Microbiol. 2015; 64:323-328.

27. Zheng Y, Xia P, Zheng HC, Takahashi H, Masuda S, Takano $\mathrm{Y}$. The screening of viral risk factors in tongue and pharyngolaryngeal squamous carcinoma. Anticancer Res. 2010; 30:1233-1238.

28. Atula S, Grenman R, Kujari H, Syrjänen S. Detection of human papillomavirus (HPV) in laryngeal carcinoma cell lines provides evidence for a heterogeneic cell population. Eur J Cancer. 1999; 35:825-832.

29. Palmieri A, Carinci F, Martinelli M, Spinelli G, Lo Muzio L, Rubini C, Scapoli L. Absence of Simian virus 40, BK, and JC polyomavirus DNA in squamous cell carcinoma limited to the oral cavity. Head Neck. 2010; 32:375-80.

30. Butel JS, Lednicky JA. Cell and molecular biology of simian virus 40: implications for human infections and disease. J Natl Cancer Inst. 1999; 91: 119-134.

31. Antonsson A, Neale RE, O'Rourke P, Wockner L, Michel A, Pawlita M, Waterboer T, Green AC. Prevalence and stability of antibodies to thirteen polyomaviruses and association with cutaneous squamous cell carcinoma: A populationbased study. J Clin Virol. 2018; 101:34-37.

32. Comar M, Bonifacio D, Zanconati F, Di Napoli M, Isidoro E, Martini F, Torelli L, Tognon M. High prevalence of BK polyomavirus sequences in human papillomavirus-16positivie precancerous cervical lesions. J Med Virol. 2011; 83:1770-6.

33. Kantola K, Sadeghi M, Lahtinen A, Koskenvuo M, Aaltonen LM, Möttönen M, Rahiala J, Saarinen-Pihkala U, Riikonen P, Jartti T, Ruuskanen O, Söderlund-Venermo M, Hedman K. Merkel Cell polyomavirus DNA in tumorfree tonsillar tissues and upper respiratory tract samples: implications for respiratory transmission and latency. J Clin Virol. 2009; 45:292-5.

34. Pyöriä L, Toppinen M, Mäntylä E, Hedman L, Aaltonen LM, Vihinen-Ranta M, Ilmarinen T, Söderlund-Venermo M, Hedman K, Perdomo MF. Extinct type of human parvovirus B19 persists in tonsillar B cells. Nat Commun. 2017; 8:14930.

35. Stolt A, Sasnauskas K, Koskela P, Lehtinen M, Dillner J. Seroepidemiology of the human polyomaviruses. J Gen Virol. 2003; 84:1499-504.

36. Knowles WA, Pipkin P, Andrews N, Vyse A, Minor P, Brown DW, Miller E. Population-based study of antibody to the human polyomaviruses BKV and JCV and the simian polyomavirus SV40. J Med Virol. 2003; 71:115-23.

37. Sadeghi M, Wang Y, Ramqvist T, Aaltonen LM, Pyöriä L, Toppinen M, Söderlund-Venermo M, Hedman K. Multiplex detection in tonsillar tissue of all known human polyomaviruses. BMC Infect Dis. 2017; 17:409.
38. Smits PH, de Ronde A, Smits HL, Minnaar RP, van der Noordaa J, ter Schegget J. Modulation of the human papillomavirus type 16 induced transformation and transcription by deletion of loci on the short arm of human chromosome 11 can be mimicked by SV40 small t. Virology. 1992; 190:40-44.

39. Herberhold S, Hellmich M, Panning M, Bartok E, Silling S, Akqul B, Wieland U. Human polyomavirus and human papillomavirus prevalence and viral load in non-malignant tonsillar tissue and tonsillar carcinoma. Med Microbiol Immunol. 2017; 206:93-103.

40. Alosaimi B, Hampson L, He X, Maranga IO, Oliver AW, Hampson IN. Increased prevalence of JC polyomavirus in cervical carcinomas from women infected with HIV. J Med Virol. 2014; 86:672-677.

41. Descamps G, Karaca Y, Lechien JR, Kindt N, Decaestecker C, Remmelink M, Larsimont D, Andry G, Hassid S, Rodriquez A, Khalife M, Journe F, Saussez S. Classical risk factors, but not HPV status, predict survival after chemoradiotherapy in advanced head and neck cancer patients. J Cancer Res Clin Oncol. 2016; 142:2185-2196.

42. Dayyani F, Etzel CJ, Liu M, Ho CH, Lippman SM, Tsao AS. Meta-analysis of the impact of human papillomavirus (HPV) on cancer risk and overall survival in head and neck squamous cell carcinomas (HNSCC). Head Neck Oncol. 2010; 2:15.

43. McNees AL, White ZS, Zanwar P, Vilchez RA, Butel JS. Specific and quantitative detection of human polyomaviruses BKV, JCV, and SV40 by real time PCR. J Clin Virol. 2005; 34:52-62.

44. Lee SH, Koo BS, Kim JM, Huang S, Rho YS, Bae WJ, Kang HJ, Kim YS, Moon JH, Lim YC. Wnt/ $\beta$-catenin signalling maintains self-renewal and tumourigenicity of head and neck squamous cell carcinoma stem-like cells by activating Oct4. J Pathol. 2014; 234:99-107.

45. Lansford CD, Grenman R, Bier H, Somers KD, Kim SY, Whiteside TL, Clayman GL, Welkoborsky JH, Carey TE. Head and Neck Cancers. Human Cell Culture. 1999; 2: $185-$ 255. https://doi.org/10.1007/0-306-46861-1_12.

46. Miller SA, Dykes DD, Polesky HF. A simple salting out procedure for extracting DNA from human nucleated cells. Nucleic Acids Res. 1988; 16:1215.

47. Rautava J, Kuuskoski J, Syrjänen K, Grenman R, Syrjänen S. HPV genotypes and their prognostic significance in head and neck squamous cell carcinomas. J Clin Virol. 2012; 53:116- 120 .

48. Schmitt M, Bravo IG, Snijders PJF, Gissman L, Pawlita M, Waterboer T. Bead-based multiplex genotyping of human papillomaviruses. J Clin Microbiol. 2006; 44:504-512. 